\title{
Heavy Metal Mining
}

National Cancer Institute

\section{Source}

National Cancer Institute. Heavy Metal Mining. NCI Thesaurus. Code C157009.

A process and occupation involving the extraction of heavy metals or their ores from the ground. 